\title{
A Protein Synthesis-Dependent Mechanism Sustains Calcium-Permeable AMPA Receptor Transmission in Nucleus Accumbens Synapses during Withdrawal from Cocaine Self-Administration
}

\author{
Andrew F. Scheyer, ${ }^{1,2}$ Marina E. Wolf, ${ }^{2 *}$ and Kuei Y. Tseng ${ }^{1 *}$ \\ ${ }^{1}$ Department of Cellular and Molecular Pharmacology and ${ }^{2}$ Department of Neuroscience, The Chicago Medical School at Rosalind Franklin University of \\ Medicine and Science, North Chicago, Illinois 60064
}

Extended-access cocaine self-administration results in withdrawal-dependent incubation of cocaine craving. Rats evaluated after $\sim 1$ month of withdrawal from such regimens ("incubated rats") exhibit changes in medium spiny neurons (MSNs) of the nucleus accumbens (NAc) that include accumulation of $\mathrm{Ca}^{2+}$-permeable AMPA receptors (CP-AMPARs) and a switch in group I metabotropic glutamate receptor (mGluR)-mediated suppression of synaptic transmission from mGluR5-dependent to mGluR1-dependent. To determine the role of protein synthesis in mediating these adaptations, we conducted whole-cell patch-clamp recordings in NAc core MSNs of "incubated rats" in the presence of translational inhibitors (anisomycin, cycloheximide, rapamycin) or the transcriptional inhibitor actinomycin-D. The contribution of CP-AMPARs to synaptic transmission was determined by the rectification index and the sensitivity to the CP-AMPAR antagonist 1-naphthyl acetyl spermine. We found that CP-AMPAR-mediated transmission in the NAc of "incubated rats" was reduced to levels comparable to those found in saline control rats when brain slices were treated with translational inhibitors, whereas actinomycin-D had no effect. We also investigated the effect of protein translation inhibitors on the switch of mGluR function in MSNs of "incubated rats" using the group I mGluR agonist (S)-3,5-dihydroxyphenylglycine in combination with either an mGluR1 (LY367385) or an mGluR5 (3-[(2-methyl-4-thiazolyl)ethynyl]pyridine) antagonist. Data revealed that inhibition of protein translation eliminated the mGluR1-mediated inhibition and restored the mGluR5 responsiveness to a state functionally similar to that of saline control rats. Together, these results suggest that aberrant regulation of local protein synthesis contributes to the maintenance of adaptations accrued at NAc MSN synapses during incubation of cocaine craving.

Key words: addiction; medium spiny neurons; mGluR; synaptic plasticity

\section{Introduction}

High-conductance GluA2-lacking $\mathrm{Ca}^{2+}$-permeable AMPA receptors (CP-AMPARs) participate in many types of synaptic plasticity (Isaac et al., 2007; Lee, 2012), including cocaineinduced plasticity in the ventral tegmental area (VTA) and nucleus accumbens (NAc; Wolf and Tseng, 2012). Our work has focused on the intensification ("incubation") of cue-induced craving that occurs over the first several months of withdrawal from extended-access cocaine self-administration (Pickens et al.,

\footnotetext{
Received Nov. 25, 2013; revised Jan. 22, 2014; accepted Jan. 22, 2014

Author contributions: A.F.S., M.E.W., and K.Y.T. designed research; A.F.S. performed research; A.F.S. and K.Y.T. analyzed data; A.F.S., M.E.W., and K.Y.T. wrote the paper.

This work was supported by National Institutes of Health Grants DA009621 to M.E.W. and K.Y.T., and DA029099 and DA015835 to MEW; a grant from Rosalind Franklin University to K.Y.T.; and a predoctoral National Research Service Award DA036327 to A.F.S.

*M.E.W. and K.Y.T. contributed equally to this work.

Correspondence should be addressed to Kuei Y. Tseng, MD, PhD, Department of Cellular and Molecular Pharmacology, The Chicago Medical School at Rosalind Franklin University of Medicine and Science, 3333 Green Bay Road, North Chicago, IL 60064. E-mail: kuei-yuan.tseng@rosalindfranklin.edu.

DOI:10.1523/JNEUROSCI.4940-13.2014

Copyright $\odot 2014$ the authors $\quad 0270-6474 / 14 / 333095-06 \$ 15.00 / 0$
}

2011). We and others have shown that the expression of incubation after prolonged withdrawal is mediated by CP-AMPARs that accumulate at excitatory synapses onto medium spiny neurons (MSNs) of the NAc (Conrad et al., 2008; Mameli et al., 2009; Loweth et al., 2014b), a brain region critical for mediating motivated behaviors, including drug-seeking (Sesack and Grace, 2010). Interestingly, this increase in NAc CP-AMPAR transmission does not emerge until $\sim 1$ month following the cessation of cocaine self-administration, but persists through at least withdrawal day 80 (Wolf and Tseng, 2012). Although the mechanism underlying CP-AMPAR accumulation is not fully understood, it is accompanied by the emergence of a form of synaptic depression in which mGluR1 activation reduces CP-AMPAR transmission to control levels (McCutcheon et al., 2011b) and thereby reduces the expression of incubated cocaine craving (Loweth et al., 2014a). These results suggest that mGluR1-based pharmacotherapies could help recovering addicts maintain abstinence (Loweth et al., 2013).

It is well established that some forms of metabotropic glutamate receptor (mGluR)-mediated long-term depression (LTD) require rapid protein translation (Lüscher and Huber, 2010). A 


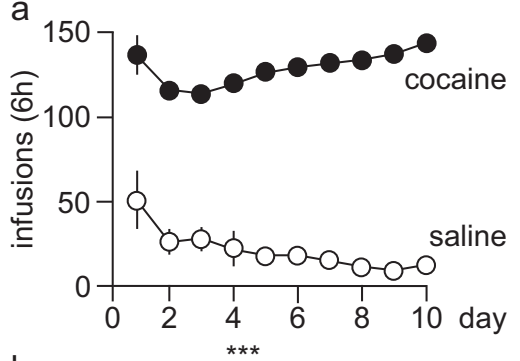

b

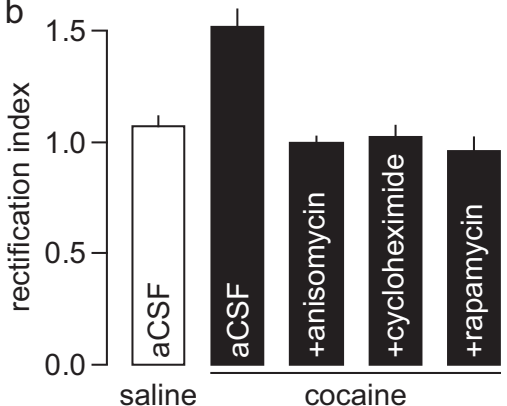

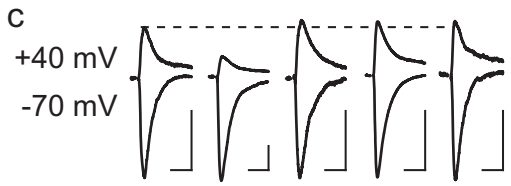

Figure 1. $\quad \boldsymbol{a}$, Graph summarizing the number of infusions of cocaine and saline during selfadministration training $(6 \mathrm{~h} / \mathrm{d}$ over $10 \mathrm{~d}) . \boldsymbol{b}, \mathrm{MSN}$ recorded from "incubated rats" $(9$ cells/ 8 rats, cocaine/aCSF group) exhibited a significantly higher RI than MSNs from saline controls (8 cells/5 rats, saline/aCSF group; ${ }^{* * *} p<0.0005$ vs other treatment groups, Tukey's posthoc test; 1 -way ANOVA, $\left.F_{(4,39)}=18.01, p<0.0001\right)$. This elevated RI was no longer observed in recordings from brain slices preincubated with anisomycin ( $25 \mu \mathrm{m}, 11$ cells/ 8 rats), cycloheximide $(25 \mu \mathrm{m}$, 9 cells $/ 6$ rats), or rapamycin ( $50 \mathrm{~nm}, 8$ cells $/ 4$ rats). Instead, the RI was reduced to levels that did not differ significantly from the saline/aCSF group. c, Example traces of evoked EPSC illustrating the RI results shown in $b$. Calibration: $50 \mathrm{pA}, 50 \mathrm{~ms}$.

specific example of this is the mGluR1-mediated LTD observed in the VTA of cocaine-exposed rats (Mameli et al., 2007; Yuan et al., 2013), which provides an important precedent for our studies because the LTD is mediated via CP-AMPAR removal. In the VTA, cocaine exposure ranging from a single injection to cocaine self-administration leads to rapid (hours) elevation of CPAMPAR levels, via an exchange process in which CP-AMPARs are inserted into synapses while GluA2-containing AMPARs are removed (Bellone and Lüscher, 2005, 2006). Stimulation of mGluR1 reverses this process via a mechanism dependent on rapid synthesis of GluA2 (Mameli et al., 2007). Although the mechanisms by which cocaine promotes CP-AMPAR accumulation in the VTA and NAc are different (the latter occurs only after prolonged withdrawal from extended-access cocaine self-administration; McCutcheon et al., 2011a; Purgianto et al., 2013), the mGluR1-mediated removal of CP-AMPARs from VTA synapses parallels that described in the NAc (McCutcheon et al., 2011b; Loweth et al., 2014a). Therefore, based on the protein synthesisdependence of mGluR1-LTD in the VTA, as well as other forms of postsynaptically expressed mGluR-LTD (Lüscher and Huber, 2010), we investigated the role of protein synthesis in mediating the synaptic adaptations observed in NAc MSNs of "incubated rats" using whole-cell patch-clamp recordings in the presence of translational and transcriptional inhibitors. To our surprise, rather than uncovering a requirement for protein synthesis in the mGluR1-mediated depression of CP-AMPAR transmission as seen in the VTA, we found that ongoing protein translation is necessary for the maintenance of CP-AMPARs in NAc synapses after prolonged withdrawal from extended-access cocaine self-administration.

\section{Materials and Methods}

All experimental procedures were approved by the Rosalind Franklin University Institutional Animal Care and Use Committee in accordance with the United States Public Health Service Guide for Care and Use of Laboratory Animals. We used adult male Sprague Dawley rats (Harlan) weighing 250-275 g upon arrival. They were housed (three per cage before surgery and one per cage after surgery) under conditions of constant temperature $\left(21-23^{\circ} \mathrm{C}\right)$ and humidity on a reverse $12 \mathrm{~h}$ light/dark cycle with food and water available ad libitum. All chemicals were purchased from Sigma-Aldrich, except for DL-APV, LY367385, and 3-[(2methyl-4-thiazolyl)ethynyl]pyridine (MTEP), which were purchased from Tocris Bioscience. Cocaine $\mathrm{HCl}$ was obtained from National Institute on Drug Abuse.

Surgery and cocaine self-administration training. All surgical and drug self-administration procedures were described in detail previously (Conrad et al., 2008). Briefly, rats were anesthetized with ketamine-xylazine ( $80-10 \mathrm{mg} / \mathrm{kg}$, i.p., respectively) and a Silastic catheter (Plastics One) was inserted into the right jugular vein and fixed in the midscapular region. During the $7 \mathrm{~d}$ recovery period and subsequent self-administration training period, catheters were flushed every $24-48 \mathrm{~h}$ with cefazolin $(15 \mathrm{mg}$ volume; Webster Veterinary Supply) in $0.9 \%$ sterile saline. Rats selfadministered cocaine $(0.5 \mathrm{mg} / \mathrm{kg} /$ infusion in a $100 \mu \mathrm{l} / \mathrm{kg}$ volume over $3 \mathrm{~s})$ or saline for $10 \mathrm{~d}(6 \mathrm{~h} / \mathrm{d})$. Self-administration chambers (MED Associates) were equipped with two holes (active and inactive) located on opposite sides of the chamber. Nose-poking in the active hole delivered an infusion of saline or cocaine paired with a $20 \mathrm{~s}$ light cue and a $20 \mathrm{~s}$ time-out period. Nose-poking in the inactive hole was without consequence. Food and water were present at all times and sessions began approximately at the beginning of the rat's dark cycle. For controls we used a combination of rats that self-administered saline and "handled control" rats that were treated in an identical manner as self-administration rats, except they were not exposed to the self-administration chambers. Instead, they were taken from their colony room to a novel holding environment for $6 \mathrm{~h} / \mathrm{d}$ for $10 \mathrm{~d}$. Thus, handled controls rats experienced the same surgery, recovery, time away from the colony, and handling as the self-administration groups. Our previous work has shown that NAc AMPAR transmission in these animals is identical to that observed in saline self-administering controls (Ferrario et al., 2011) and in drugnaive rats (our unpublished observations).

Whole-cell patch-clamp recordings in the NAc. All electrophysiological procedures were adapted from those previously described (Conrad et al., 2008; McCutcheon et al., 2011a,b). Briefly, rats were anesthetized with chloral-hydrate $(400-600 \mathrm{mg} / \mathrm{kg}$, i.p.) and the brains were rapidly removed. Coronal slices at the level of the NAc $(350 \mu \mathrm{m})$ were cut with a vibrating microtome in ice-cold oxygenated $\left(95 \% \mathrm{O}_{2}-5 \% \mathrm{CO}_{2}\right)$ artificial CSF (aCSF) solution containing the following (in $\mathrm{mM}$ ): $122.5 \mathrm{NaCl}, 20$ glucose, $25 \mathrm{NaHCO}_{3}, 2.5 \mathrm{KCl}, 0.5 \mathrm{CaCl}_{2}, 3 \mathrm{MgCl}_{2}, 1 \mathrm{NaH}_{2} \mathrm{PO}_{4}, 1$ ascorbic acid. The slices were then incubated in warm aCSF $\left(32-34^{\circ} \mathrm{C}\right)$ for at least $1 \mathrm{~h}$ before transferring into the recording chamber. In the recording aCSF, $\mathrm{CaCl}_{2}$ was increased to $2.5 \mathrm{~mm}$ and $\mathrm{MgCl}_{2}$ was reduced to $1 \mathrm{~mm}$. Both picrotoxin $(0.1 \mathrm{~mm})$ and $(2 \mathrm{R})$-amino-5-phosphonopentanoate $(0.05 \mathrm{mM})$ were added into the recording aCSF to pharmacologically isolate AMPAR transmission. All recordings were conducted at $32-34^{\circ} \mathrm{C}$ using patch pipettes $(6-8 \mathrm{M} \Omega)$ filled with a Cs-based/sperminecontaining internal solution (in mM): $140 \mathrm{CsCl}, 10 \mathrm{HEPES}, 2 \mathrm{MgCl}_{2}, 5$ NaATP, 0.6 NaGTP, 2 QX-314, 0.1 spermine. A bipolar tungsten stimulating electrode placed $\sim 200 \mu \mathrm{m}$ from the recording site was used to elicit EPSCs in MSNs. Only neurons that exhibited a stable synaptic response ( $<15 \%$ variability) during $15 \mathrm{~min}$ of baseline recording were included. The rectification index (RI) was calculated as follows: $\left[\right.$ EPSC $\left._{-70 \mathrm{mV}} /\left(-70-E_{\text {rev }}\right)\right] /\left[\mathrm{EPSC}_{+40 \mathrm{mV}} /\left(+40-E_{\text {rev }}\right)\right]$. All measures of CP-AMPAR transmission were obtained from brain slices preincubated for $>60 \mathrm{~min}$ in recording aCSF alone or aCSF plus a translational or transcriptional inhibitor. 

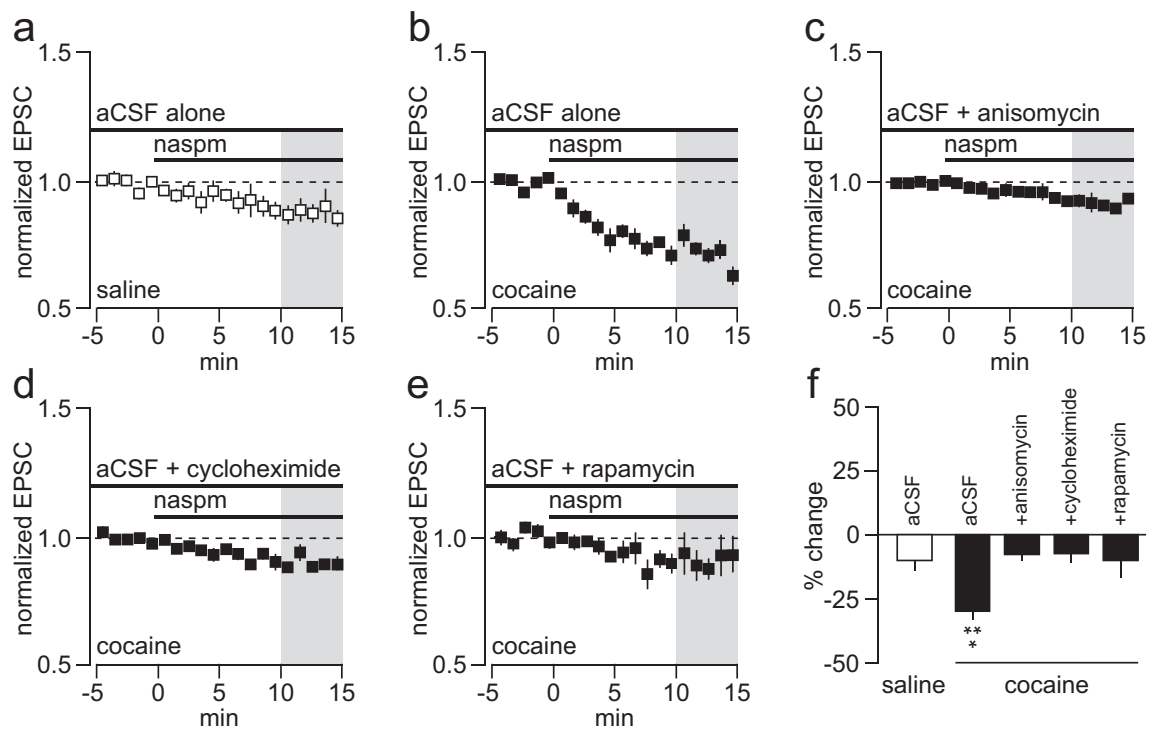

Figure 2. $\quad \boldsymbol{a}$, Bath application of naspm ( $100 \mu \mathrm{m})$ reduced the amplitude of EPSC $-70 \mathrm{mv}$ by $\sim 10 \%$ in NAc MSNs recorded from saline controls ( 6 cells $/ 5$ rats; $p=0.04$, baseline vs the last 5 min of naspm, paired $t$ test). $\boldsymbol{b}$, In NAc brain slices obtained from "incubated rats," the magnitude of naspm-induced EPSC $-70 \mathrm{mv}$ inhibition was markedly greater ( $\sim 30 \% ; 8$ cells $/ 5$ rats; $p<$ 0.0001 , baseline vs the last 5 min of naspm, paired $t$ test). $(-e$, Similar recordings from NAc brain slices of "incubated rats" performed in the presence of anisomycin ( $25 \mu \mathrm{m} ; 5$ cells/5 rats), cycloheximide ( $25 \mu \mathrm{m} ; 6$ cells $/ 3$ rats), or rapamycin $(50 \mathrm{~nm} ; 7$ cells $/ 6$ rats) revealed an attenuated effect of naspm. $\boldsymbol{f}$, Bar graph summarizing the magnitude of naspm-induced inhibition of MSN EPSC $-70 \mathrm{mv}$ amplitude shown in $\boldsymbol{a}-\boldsymbol{e}$. The average values were calculated from the last $5 \mathrm{~min}$ of naspm application $\left({ }^{* *} p<0.005\right.$ vs anisomycin, cycloheximide, or rapamycin; ${ }^{*} p<0.05$ vs saline, Tukey's post hoc test after significant 1 -way ANOVA, $F_{(4,28)}=6.0$, $p<0.002)$.
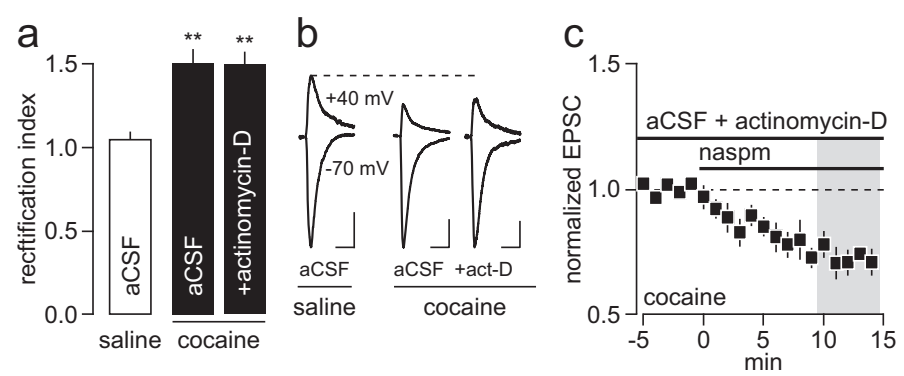

Figure 3. a, Summary of the RI recorded from NAc MSNs of "incubated rats" in the presence of actinomycin-D ( $25 \mu \mathrm{M}, 9$ cells/4 rats). Data from saline/aCSF and cocaine/aCSF (Fig. 1b) groups were included to show that actinomycin-D failed to normalize the characteristic elevated RI observed in NAc MSNs from "incubated rats" ( ${ }^{* *} p<0.005$ vs saline, Tukey's post hoc test; 1-way ANOVA, $\left.F_{(2,25)}=12.9, p<0.0001\right) \cdot \boldsymbol{b}$, Example traces of evoked EPSC $-70 \mathrm{mv}$ and EPSC $+40 \mathrm{mv}$ recorded from NAc MSNs illustrating the RI results shown in $\boldsymbol{a}$. Calibration: $50 \mathrm{pA}, 50 \mathrm{~ms}$. c, Actinomycin-D also failed to reduce the inhibitory effect of naspm (100 $\mu \mathrm{M}$ ) on MSN EPSC $-70 \mathrm{mv}$ amplitude recorded from NAc brain slices of "incubated rats" ( 6 cells $/ 5$ rats). $\boldsymbol{d}$, Bar graph summarizing the magnitude of naspm-induced inhibition of MSN EPSC $-70 \mathrm{mv}$ amplitude calculated from the last 5 min of drug application ( ${ }^{*} p<0.05$ vs saline, Tukey's post hoc test; 1 -way ANOVA, $\left.F_{(2,17)}=6.8, p<0.007\right)$.

Statistical analyses. Data are expressed as mean \pm SEM. Student's $t$ tests were used for two-group comparisons involving a single variable, whereas ANOVA was used for comparing the effects along $\geq 2$ variables. Differences between experimental conditions were considered statistically significant when $p<0.05$.

\section{Results}

All MSN recordings were from the NAc core of adult rats following $>40 \mathrm{~d}$ withdrawal from extended-access cocaine ("incubated rats") or saline self-administration (Fig. 1a). As shown previously (Conrad et al., 2008; McCutcheon et al., 2011a,b; Loweth et al., 2014a), CP-AMPAR transmission onto NAc MSN is enhanced in "incubated rats" as revealed by the elevated RI of AMPARmediated EPSCs (Fig. 1b,c). As a first step in understanding the

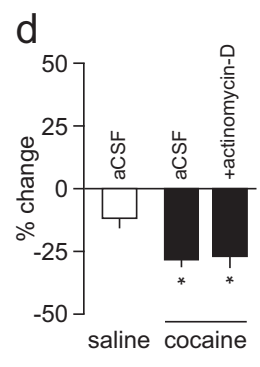

role of protein synthesis in incubationassociated neuroadaptations, the RI was compared in brain slices of "incubated rats” after exposure (>60 $\mathrm{min}$ ) to aCSF (control condition) or one of the following translational inhibitors: anisomycin $(25 \mu \mathrm{M})$, cycloheximide $(25 \mu \mathrm{M})$, or rapamycin (50 nM). Results showed that the characteristic increased RI observed in MSNs of "incubated rats" is no longer present in slices treated with any of these inhibitors (Fig. $1 b, c$ ). In fact, all translational inhibitors reduced the RI to a level that was indistinguishable from MSNs recorded in brain slices of control rats that self-administered saline (Fig. $1 b, c$ ). We next assessed the effects of the CP-AMPAR antagonist 1-naphthyl acetyl spermine (naspm, $100 \mu \mathrm{M}$ ) in a subset of brain slices pre-exposed to the translational inhibitors to verify that the observed normalization of the RI was due to a suppression of CP-AMPAR transmission (Fig. 2). Consistent with our previous studies (Conrad et al., 2008; McCutcheon et al., 2011a,b; Purgianto et al., 2013; Loweth et al., 2014a), bath application of naspm reduced EPSC $-70 \mathrm{mV}$ amplitude by $~ 10 \%$ in MSNs recorded from saline control rats (Fig. 2a), whereas a significantly greater inhibition of AMPAR synaptic transmission ( $\sim 30 \%)$ was observed in the NAc of "incubated rats" (Fig. 2b). However, recordings from brain slices of "incubated rats” treated with anisomycin, cycloheximide, or rapamycin revealed a marked attenuation of naspm-induced synaptic inhibition (Fig. $2 c-e$ ). Both the time course and magnitude of EPSC $-70 \mathrm{mv}$ attenuation elicited by naspm across all translational inhibitor-treated NAc slices were comparable to those observed in saline control rats (Fig. $2 f$ ). In summary, these results indicate a crucial role for ongoing protein synthesis in sustaining the abnormally elevated CP-AMPAR transmission found at NAc synapses from "incubated rats."

To determine whether protein transcription is required to maintain elevated CP-AMPAR transmission, a subset of NAc brain slices from "incubated rats" was pre-exposed (>60 min) to the transcriptional inhibitor actinomycin-D $(25 \mu \mathrm{M})$, and changes in RI and naspm sensitivity were assessed. Data show that actinomycin-D failed to reduce the elevated RI or to attenuate the inhibitory effect of naspm on EPSC $_{-70 \mathrm{mV}}$ amplitude (Fig. 3). These results suggest that ongoing transcription is not required to sustain the abnormally enhanced CP-AMPAR transmission observed in the NAc of "incubated rats."

Finally, we asked whether the reversal of elevated CPAMPAR transmission following inhibition of protein translation is accompanied by a normalization of the altered mGluR plasticity observed in the NAc of "incubated rats." 
Typically, the group I mGluR agonist (S)-3,5-dihydroxyphenylglycine (DHPG)induced synaptic inhibition in the NAc is mediated by mGluR5 activation (Robbe et al., 2002; McCutcheon et al., 2011b). In contrast, an mGluR1-mediated, PKCdependent inhibition of MSN EPSC -70 $\mathrm{mv}$ resulting from removal of CP-AMPAR transmission emerges in the NAc of "incubated rats" (McCutcheon et al., 2011b). Here, we found that DHPG continues to exert an inhibitory effect on MSN EPSC $_{-70 \mathrm{mV}}$ in NAc slices from "incubated rats" in the presence of protein translation inhibitors (Fig. 4a,b). However, in contrast to slices from "incubated rats" recorded in normal aCSF (McCutcheon et al., 2011b), the effect of DHPG in the presence of translational inhibitors was not blocked by the mGluR1 antagonist LY367385, indicating that mGluR1 transmission no longer mediates the DHPGinduced synaptic depression (Fig. $4 c, d$ ). Instead, DHPG-mediated inhibition of EPSC $_{70 \mathrm{mV}}$ was dependent upon activation of mGluR 5 as revealed by its blockade with the mGluR5 antagonist MTEP (Fig. $4 e, f)$. Together, these findings indicate a crucial role for ongoing protein synthesis in sustaining the altered mGluR plasticity observed in the NAc of "incubated rats" (Fig. 4g,h).

\section{Discussion}

During prolonged withdrawal from extended-access cocaine self-administration, glutamatergic transmission onto MSN of the NAc undergoes substantial changes, including the accumulation of CP-AMPARs and the appearance of an mGluR1dependent form of synaptic depression instead of the normal mGluR5-mediated inhibition (Conrad et al., 2008; McCutcheon et al., 2011b). Results from the present study demonstrate that these adaptations require ongoing protein translation, but not transcription. Specifically, we found that pharmacological disruption of protein translation reduced the abnormally elevated CP-AMPAR transmission and restored the responsiveness of group I mGluR transmission in the NAc of "incubated rats" to a state functionally similar to that of saline controls.

The accumulation of CP-AMPARs at NAc MSN synapses during withdrawal from extended-access cocaine self-administration has been established as a crucial adaptation mediating the expression of cocaine craving (Conrad et al., 2008; Loweth et al., 2014a,b). By measuring the RI and the magnitude of synaptic inhibition induced by the CP-AMPAR antagonist naspm, we made the unexpected finding that a mechanism dependent on protein translation contributes to sustaining the elevated CPAMPAR transmission observed in NAc synapses of "incubated rats." Interestingly, inhibition of transcription with actinomycin-D failed to reproduce the effects of translational inhibitors, arguing against the possibility that the adaptations occurring in NAc synapses during incubation reflect epigenetic changes. Furthermore, the efficacy of rapamycin, which works by inhibiting the mammalian target of rapamycin (a key regulator of dendritic translation; Costa-Mattioli and Monteggia, 2013), suggests that these a, c, e, g: pooled data from the 3 translational inhibitors

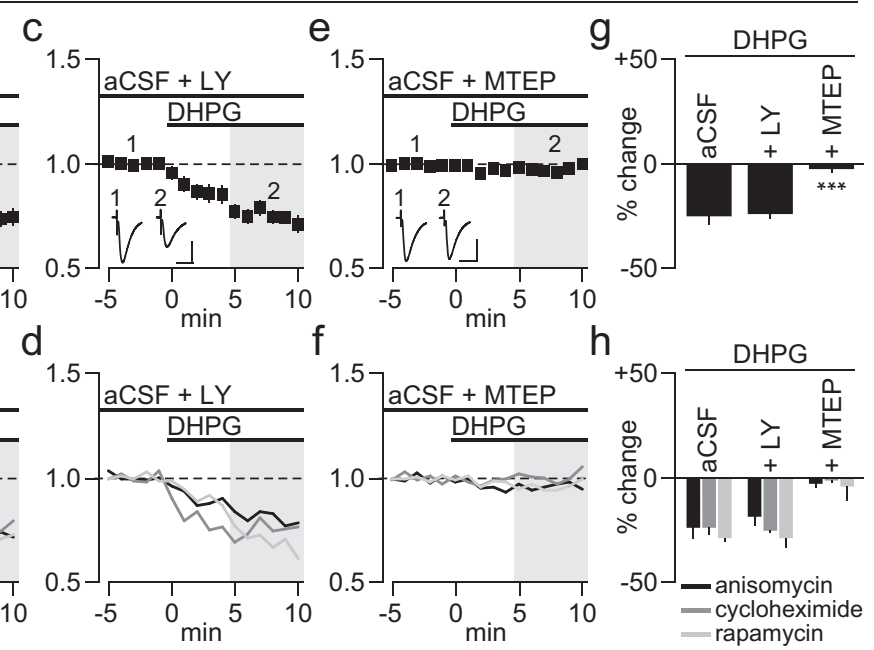

Impact of protein translation inhibitors on DHPG $(50 \mu \mathrm{m})$-induced attenuation of MSN EPSC $-70 \mathrm{mv}$ amplitude f EPSC $70 \mathrm{mv}$ amplitude in the absence of mGluR antagonists ( $p<0.0005$, baseline vs the last $5 \mathrm{~min}$ of DHPG, paired $t$ test). Note in in the recording aCSF failed to block the inhibitory effect of DHPG on MSN EPSC $-70 \mathrm{mv}$ amplitude $(p<0.0005$, baseline vs the last (test). Both the pattern and magnitude of DHPG-induced attenuation of EPSC $-70 \mathrm{mv}$ amplitude were test; 1 -way ANOVA, $\left.F_{(2,37)}=21.62, p<0.0001\right)$. Inset traces in $\boldsymbol{a}, c_{\text {, and }}$ are examples of evoked EPSC $-70 \mathrm{mV}$ recorded from NAc MSN before (1) and after (2) bath application of DHPG in the presence of rapamycin. Calibration: $50 \mathrm{pA}, 25 \mathrm{~ms}$.

adaptations result from abnormal regulation of protein translation in NAc dendrites, as discussed further below.

The maintenance of AMPARs in synapses depends on complex interactions with scaffolding proteins at the postsynaptic density (Anggono and Huganir, 2012). Based on our results, we propose that translational inhibition for $\sim 1 \mathrm{~h}$ leads to depletion of a protein(s) that is specifically required for synaptic stabilization of CP-AMPARs. The identity of such a protein(s) remains unknown. The time course of our experiment suggests that the target of interference must have a short half-life since substantial depletion must occur within $1 \mathrm{~h}$. One candidate is Arc, a protein whose translation is rapidly regulated during synaptic plasticity (Park et al., 2008; Waung et al., 2008) and has been implicated in removing AMPARs from synapses (Chowdhury et al., 2006; Rial Verde et al., 2006; Shepherd et al., 2006; Béique et al., 2011; but see Giorgi et al., 2007). By increasing the rate of constitutive internalization of GluA2-containing AMPARs, Arc translation has been shown to increase the proportion of CP-AMPARs in synapses of retinal ganglion cells during homeostatic plasticity (Xia et al., 2007). Alternatively, a regulator of Arc may be a potential target to explain the disruption in CP-AMPAR maintenance induced by the translational inhibitors (Greer et al., 2010). Rapid translational regulation of a protein that impacts the function of transmembrane AMPA receptor regulatory proteins (TARPs) could also play a role in sustaining CP-AMPARs at NAc synapses, as indicated by recent work in cerebellar granule cells (Studniarczyk et al., 2013). Finally, we cannot rule out the possibility that ongoing translation of GluAl is required to maintain CP-AMPARs since most CP-AMPARs accumulating in the NAc 
of "incubated rats" are homomeric GluA1 (Conrad et al., 2008). Although metabolic turnover studies report half-lives of days for GluA subunits (Cohen et al., 2013), synaptic pools may turn over more rapidly (Ehlers, 2003).

In the NAc of "incubated rats," activation of mGluR1 decreases or eliminates CP-AMPAR transmission, resulting in synaptic depression (McCutcheon et al., 2011b). Given the requirement for protein synthesis in many forms of group I mGluR-LTD (Lüscher and Huber, 2010), we also investigated the role of protein synthesis in the altered mGluR function observed in the NAc of "incubated rats." We found that the mGluR1mediated inhibition of synaptic transmission was absent in the presence of translational inhibitors. Such an effect was not completely unexpected since the level of CP-AMPARs, the substrate for this form of synaptic regulation, was substantially diminished by the translational inhibitors. Interestingly, protein translation inhibition also restored the mGluR5 function that was absent following prolonged withdrawal from cocaine self-administration (McCutcheon et al., 2011b). In naive and saline control rats, mGluR5-mediated synaptic depression is mediated by a presynaptic CB1R-dependent attenuation of transmitter release (Robbe et al., 2002). Our results suggest that aberrant local protein synthesis during incubation disrupts some components of this mGluR5 transmission pathway. Thus, inhibiting protein translation enables the reappearance of mGluR5-mediated synaptic depression.

In conclusion, our results implicate dysregulated protein translation as crucial in maintaining persistent synaptic adaptations observed in the NAc of "incubated rats" (Conrad et al., 2008; Loweth et al., 2014a,b). Among these adaptations, the elevation of CP-AMPAR levels is particularly important because they mediate the expression of incubation (Conrad et al., 2008). At earlier times, it is likely that adaptations in other brain regions are responsible for incubation (Pickens et al., 2011). We note that different cocaine regimens lead to different AMPAR plasticity in NAc synapses (McCutcheon et al., 2011a; Purgianto et al., 2013). However, it is important to understand mechanisms underlying CP-AMPAR accumulation, as well as related adaptations in the NAc of "incubated rats," because of the relevance of the incubation model to relapse in abstinent cocaine users (Reichel and Bevins, 2009; Pickens et al., 2011). Whether the same mechanisms are relevant to incubation of craving for other drugs of abuse remains to be determined; for example, both similarities and differences have been described for mechanisms contributing to incubation of craving for heroin versus cocaine (Pickens et al., 2011). Nevertheless, our present study complements prior studies that have implicated protein translation in other aspects of cocaine addiction (Lee et al., 2005; Miller and Marshall, 2005; Dayas et al., 2012). Future studies are needed to identify the cellular mechanisms responsible for persistent dysregulation of translation in the NAc of "incubated rats," which in turn could provide novel potential targets for therapeutic interventions. Although the analogy should not be overstated, it is interesting that dysregulated local protein synthesis plays a key role in maintaining aberrant synaptic characteristics in fragile X syndrome, and that pharmacotherapies aimed at reducing protein synthesis show potential for treating this disorder (Bhakar et al., 2012).

\section{References}

Anggono V, Huganir RL (2012) Regulation of AMPA receptor trafficking and synaptic plasticity. Curr Opin Neurobiol 22:461-469. CrossRef Medline

Béique JC, Na Y, Kuhl D, Worley PF, Huganir RL (2011) Arc-dependent synapse-specific homeostatic plasticity. Proc Natl Acad Sci U S A 108: 816-821. CrossRef Medline
Bellone C, Lüscher C (2005) mGluRs induce a long-term depression in the ventral tegmental area that involves a switch of the subunit composition of AMPA receptors. Eur J Neurosci 21:1280-1288. CrossRef Medline

Bellone C, Lüscher C (2006) Cocaine triggered AMPA receptor redistribution is reversed in vivo by mGluR-dependent long-term depression. Nat Neurosci 9:636-641. CrossRef Medline

Bhakar AL, Dölen G, Bear MF (2012) The pathophysiology of fragile X (and what it teaches us about synapses). Annu Rev Neurosci 35:417-443. CrossRef Medline

Chowdhury S, Shepherd JD, Okuno H, Lyford G, Petralia RS, Plath N, Kuhl D, Huganir RL, Worley PF (2006) Arc/Arg3.1 interacts with the endocytic machinery to regulate AMPA receptor trafficking. Neuron 52:445459. CrossRef Medline

Cohen LD, Zuchman R, Sorokina O, Müller A, Dieterich DC, Armstrong JD, Ziv T, Ziv NE (2013) Metabolic turnover of synaptic proteins: kinetics, interdependencies and implications for synaptic maintenance. PloS One 8:e63191. CrossRef Medline

Conrad KL, Tseng KY, Uejima JL, Reimers JM, Heng LJ, Shaham Y, Marinelli M, Wolf ME (2008) Formation of accumbens GluR2-lacking AMPA receptors mediates incubation of cocaine craving. Nature 454:118-121. CrossRef Medline

Costa-Mattioli M, Monteggia LM (2013) mTOR complexes in neurodevelopmental and neuropsychiatric disorders. Nat Neurosci 16:1537-1543. CrossRef Medline

Dayas CV, Smith DW, Dunkley PR (2012) An emerging role for the mammalian target of rapamycin in "pathological" protein translation: relevance to cocaine addiction. Front Pharmacol 3:13. CrossRef Medline

Ehlers MD (2003) Activity level controls postsynaptic composition and signaling via the ubiquitin-proteasome system. Nat Neurosci 6:231-242. CrossRef Medline

Ferrario CR, Loweth JA, Milovanovic M, Ford KA, Galiñanes GL, Heng LJ, Tseng KY, Wolf ME (2011) Alterations in AMPA receptor subunits and TARPs in the rat nucleus accumbens related to the formation of $\mathrm{Ca}^{2+}$ permeable AMPA receptors during the incubation of cocaine craving. Neuropharmacology 61:1141-1151. CrossRef Medline

Giorgi C, Yeo GW, Stone ME, Katz DB, Burge C, Turrigiano G, Moore MJ (2007) The EJC factor eIF4AIII modulates synaptic strength and neuronal protein expression. Cell 130:179-191. CrossRef Medline

Greer PL, Hanayama R, Bloodgood BL, Mardinly AR, Lipton DM, Flavell SW, Kim TK, Griffith EC, Waldon Z, Maehr R, Ploegh HL, Chowdhury S, Worley PF, Steen J, Greenberg ME (2010) The Angelman syndrome protein Ube3A regulates synapse development by ubiquitinating arc. Cell 140:704-716. CrossRef Medline

Isaac JT, Ashby MC, McBain CJ (2007) The role of the GluR2 subunit in AMPA receptor function and synaptic plasticity. Neuron 54:859-871. CrossRef Medline

Lee HK (2012) Ca-permeable AMPA receptors in homeostatic synaptic plasticity. Front Mol Neurosci 5:17. CrossRef Medline

Lee JL, Di Ciano P, Thomas KL, Everitt BJ (2005) Disrupting reconsolidation of drug memories reduces cocaine-seeking behavior. Neuron 47: 795-801. CrossRef Medline

Loweth JA, Tseng KY, Wolf ME (2013) Using metabotropic glutamate receptors to modulate cocaine's synaptic and behavioral effects: mGluR1 finds a niche. Curr Opin Neurobiol 23:500-506. CrossRef Medline

Loweth JA, Scheyer AF, Milovanovic M, Lacrosse AL, Flores-Barrera E, Werner CT, Li X, Ford KA, Olive MF, Le T, Szumlinski KK, Tseng KY, Wolf ME (2014a) Synaptic depression via positive allosteric modulation of mGluR1 suppresses cue-induced cocaine craving. Nat Neurosci 17:7380. CrossRef Medline

Loweth JA, Tseng KY, Wolf ME (2014b) Adaptations in AMPA receptor transmission in the nucleus accumbens contributing to incubation of cocaine craving. Neuropharmacology 76:287-300. CrossRef Medline

Lüscher C, Huber KM (2010) Group 1 mGluR-dependent synaptic longterm depression: mechanisms and implications for circuitry and disease. Neuron 65:445-459. CrossRef Medline

Mameli M, Balland B, Luján R, Lüscher C (2007) Rapid synthesis and synaptic insertion of GluR2 for mGluR-LTD in the ventral tegmental area. Science 317:530-533. CrossRef Medline

Mameli M, Halbout B, Creton C, Engblom D, Parkitna JR, Spanagel R, Lüscher C (2009) Cocaine-evoked synaptic plasticity: persistence in the VTA triggers adaptations in the NAc. Nat Neurosci 12:1036-1041. CrossRef Medline 
McCutcheon JE, Wang X, Tseng KY, Wolf ME, Marinelli M (2011a) Calcium-permeable AMPA receptors are present in nucleus accumbens synapses after prolonged withdrawal from cocaine self-administration but not experimenter-administered cocaine. J Neurosci 31:5737-5743. CrossRef Medline

McCutcheon JE, Loweth JA, Ford KA, Marinelli M, Wolf ME, Tseng KY (2011b) Group I mGluR activation reverses cocaine-induced accumulation of calcium-permeable AMPA receptors in nucleus accumbens synapses via a protein kinase C-dependent mechanism. J Neurosci 31:14536-14541. CrossRef Medline

Miller CA, Marshall JF (2005) Molecular substrates for retrieval and reconsolidation of cocaine-associated contextual memory. Neuron 47:873884. CrossRef Medline

Park S, Park JM, Kim S, Kim JA, Shepherd JD, Smith-Hicks CL, Chowdhury S, Kaufmann W, Kuhl D, Ryazanov AG, Huganir RL, Linden DJ, Worley PF (2008) Elongation factor 2 and fragile X mental retardation protein control the dynamic translation of Arc/Arg3.1 essential for mGluR-LTD. Neuron 59:70-83. CrossRef Medline

Pickens CL, Airavaara M, Theberge F, Fanous S, Hope BT, Shaham Y (2011) Neurobiology of the incubation of drug craving. Trends Neurosci 34:411420. CrossRef Medline

Purgianto A, Scheyer AF, Loweth JA, Ford KA, Tseng KY, Wolf ME (2013) Different adaptations in AMPA receptor transmission in the nucleus accumbens after short vs long access cocaine self-administration regimens. Neuropsychopharmacology 38:1789-1797. CrossRef Medline

Reichel CM, Bevins RA (2009) Forced abstinence model of relapse to study pharmacological treatments of substance use disorder. Curr Drug Abuse Rev 2:184-194. CrossRef Medline
Rial Verde EM, Lee-Osbourne J, Worley PF, Malinow R, Cline HT (2006) Increased expression of the immediate-early gene arc/arg3.1 reduces AMPA receptor-mediated synaptic transmission. Neuron 52:461-474. CrossRef Medline

Robbe D, Kopf M, Remaury A, Bockaert J, Manzoni OJ (2002) Endogenous cannabinoids mediate long-term synaptic depression in the nucleus accumbens. Proc Natl Acad Sci U S A 99:8384-8388. CrossRef Medline

Sesack SR, Grace AA (2010) Cortico-basal ganglia reward network: microcircuitry. Neuropsychopharmacology 35:27-47. CrossRef Medline

Shepherd JD, Rumbaugh G, Wu J, Chowdhury S, Plath N, Kuhl D, Huganir RL, Worley PF (2006) Arc/Arg3.1 mediates homeostatic synaptic scaling of AMPA receptors. Neuron 52:475-484. CrossRef Medline

Studniarczyk D, Coombs I, Cull-Candy SG, Farrant M (2013) TARP gamma-7 selectively enhances synaptic expression of calcium-permeable AMPARs. Nat Neurosci 16:1266-1274. CrossRef Medline

Waung MW, Pfeiffer BE, Nosyreva ED, Ronesi JA, Huber KM (2008) Rapid translation of Arc/Arg3.1 selectively mediates mGluR-dependent LTD through persistent increases in AMPAR endocytosis rate. Neuron 59:8497. CrossRef Medline

Wolf ME, Tseng KY (2012) Calcium-permeable AMPA receptors in the VTA and nucleus accumbens after cocaine exposure: when, how, and why? Front Mol Neurosci 5:72. CrossRef Medline

Xia Y, Nawy S, Carroll RC (2007) Activity-dependent synaptic plasticity in retinal ganglion cells. J Neurosci 27:12221-12229. CrossRef Medline

Yuan T, Mameli M, O'Connor EC, Dey PN, Verpelli C, Sala C, Perez-Otano I, Lüscher C, Bellone C (2013) Expression of cocaine-evoked synaptic plasticity by GluN3A-containing NMDA receptors. Neuron 80:10251038. CrossRef Medline 